\title{
COMPARISON OF FIVE METHODS FOR OXACILLIN SUSCEPTIBILITY TESTING OF Staphylococcus aureus ISOLATES FROM CYSTIC FIBROSIS PATIENTS
}

\author{
Marcelo J. MIMICA(1,2), Rozane L. CARVALHO(1), Eitan N. BEREZIN(2), Neiva DAMACENO(3) \& Hélio H. CAIAFFA-FILHO(4)
}

\begin{abstract}
SUMMARY
Methicillin-resistant Staphylococcus aureus (MRSA) are now a worldwide problem. Cystic fibrosis (CF) patients are commonly colonized and infected by MRSA. Accurate oxacillin susceptibility testing is mandatory for the adequate management of these patients. We performed a comparison of the accuracy of different tests in CF isolates, including methicillin-susceptible $S$. aureus and MRSA with different SCCmec types, and using the mecA gene as the gold-standard. The sensitivity and specificity of oxacillin disc, Etest, and oxacillin agar screening plate were $100 \%$. Sensitivity of the cefoxitin disc was $85 \%$ and specificity was $100 \%$. For clinically relevant isolates, laboratories may consider the use of a combination of two phenotypic methods.
\end{abstract}

KEYWORDS: Oxacillin; Cefoxitin; Staphylococcus aureus; mecA; Cystic fibrosis; MRSA.

\section{INTRODUCTION}

During the last decade, new clones of methicillin- resistant $S$. aureus (MRSA) have emerged in different parts of the world, including our country ${ }^{9}$. Part of these novel isolates are community-associated MRSA (CA-MRSA), typically carrying a Staphylococcal Cassette Chromosome mec (SCCmec) type IV, and also lukS-PV and $l u k F-P V$, the genes encoding Panton-Valentine leukocidin, a specific virulence factor ${ }^{10}$.

Cystic fibrosis patients are frequently colonized and infected with Staphylococcus aureus, including $\mathrm{MRSA}^{7}$. Accurate detection of methicillin resistance in cystic fibrosis isolates is vital, since even in non-invasive isolates an inaccurate susceptibility test could lead to inappropriate antimicrobial therapy.

Although the mecA gene, that encodes methicillin resistance in $S$. aureus, is considered the gold standard test, it is not generally used in routine clinical testing, because of financial and technical issues. There are several studies in the biomedical literature regarding different oxacillin phenotypic susceptibility tests for $S$. aureus $^{1,2,4-6,8,12-15,17,18}$, but, to our knowledge, none has included only cystic fibrosis isolates. Thus, the aim of the present study was to determine the accuracy of phenotypic oxacillin susceptibility methods in Staphylococcus aureus cystic fibrosis isolates with different $\mathrm{SCCmec}$ types.

\section{METHODS}

Our pediatric department is part of a large, tertiary general hospital in São Paulo, Brazil. In our cystic fibrosis clinic, 110 patients are followed monthly or bimonthly. In these occasions, upper respiratory tract samples are routinely collected for culture.
We included in our study $S$. aureus isolated from these patients during the period from January 2004 to December 2005. We included only one isolate for patient (the first isolate during the study period).

Isolates were tested with oxacillin $(1 \mu \mathrm{g})$ and cefoxitin $(30 \mu \mathrm{g})$ discs, using Mueller-Hinton agar plates inoculated with a suspension (equivalent to a $0.5 \mathrm{McF}$ arland standard) of the $S$. aureus clinical isolates. The plates were incubated at $35^{\circ} \mathrm{C}$ for 24 hours and inhibition zones were measured. The susceptibility to oxacillin was also determined by Etest (AB Biodisk, Solna, Sweden), using Mueller-Hinton agar plates supplemented with 2\% $\mathrm{NaCl}$, and by oxacillin agar screening, that was performed by inoculating a direct colony suspension ( $0.5 \mathrm{McF}$ arland standard) with a swab, spotting an area 10 to $15 \mathrm{~mm}$ in diameter, on Mueller-Hinton agar supplemented with $4 \% \mathrm{NaCl}$ and oxacillin at $6 \mathrm{mg} / \mathrm{L}$. After incubation for 24 hours, any growth was interpreted as a positive result for MRSA.

The inhibition zones and minimum inhibitory concentration breakpoints used for interpretation were those recommended by $\mathrm{CLSI}^{3}$. The mecA gene was detected by polymerase chain reaction (PCR), as described by VANNUFFEL et al. ${ }^{16}$, and was considered the gold standard test for oxacillin resistance. SCCmec typing was performed with a multiplex (PCR) protocol previously described by OLIVEIRA et $a l .{ }^{11}$. The study was approved by the Ethics Committee at our institution.

\section{RESULTS AND DISCUSSION}

During the study period, there were $30 \mathrm{~S}$. aureus isolates from different patients $(27 \%$ of the patients were colonized with $S$. aureus at least once during the period). Seven were $m e c A$-positive. The specificity of all four phenotypic methods, using the mecA results as gold standard, was $100 \%$. The sensitivity of oxacillin disc, Etest, and oxacillin screening

(1) Division of Microbiology, Department of Pathology, Santa Casa School of Medicine, São Paulo, SP, Brazil

(2) Division of Infectious Diseases, Department of Pediatrics, Santa Casa School of Medicine, São Paulo, SP, Brazil.

(3) Division of Pulmonology, Department of Pediatrics, Santa Casa School of Medicine, São Paulo, SP, Brazil.

(4) Laboratory of Medical Investigation - LIM 03, Hospital das Clinicas-FMUSP; São Paulo, SP, Brazil.

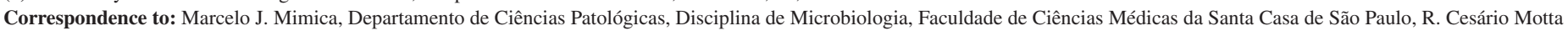
Jr 112. São Paulo, SP, Brasil. E-mail: mjmimica@ hotmail.com 
MIMICA, M.J.; CARVALHO, R.L.; BEREZIN, E.N.; DAMACENO, N. \& CAIAFFA-FILHO, H.H. - Comparison of five methods for oxacillin susceptibility testing of Staphylococcus aureus isolates from cystic fibrosis patients. Rev. Inst. Med. Trop. Sao Paulo, 54(6): 305-6, 2012.

plate was also $100 \%$. The sensitivity of the cefoxitin disc test was $85 \%$, due to a discrepant result in one isolate.

Of the seven mecA-positive isolates, four were available for SCCmec typing. Of these four, three carried SCCmec type III and one carried SCCmec type IV. The isolate with SCCmec IV and one of the three $m e c A$-positive isolates that were unavailable for typing were resistant only to penicillin, oxacillin and erythromycin. All other five isolates were multiresistant.

Most clinical laboratories throughout the world rely on disc diffusion testing for the detection of methicillin resistance in $S$. aureus. Other available routine tests include epsilometer test and oxacillin agar screening plate. Although recommended by guidelines and validated in multiple studies $^{1-6,8,12-15,17,18}$, there is a lack of data about the accuracy of these tests in isolates from such a specific population as cystic fibrosis patients.

In our study, performed in a relatively small number of isolates, we demonstrated the possibility of occurrence of major errors, with a high potential for clinical impact, when only one of this tests is used. Errors in routine oxacillin susceptibility tests, including disc diffusion with either oxacillin or cefoxitin with different breakpoints, have also been reported elsewhere ${ }^{4,8,14}$. Laboratories may consider using two methods (cefoxitin disc plus oxacillin disc; or oxacillin agar plate plus disc diffusion, per example) when testing clinically relevant isolates.

\section{RESUMO}

\section{Comparação entre cinco métodos para avaliação de susceptibilidade à oxacilina em cepas de Staphylococcus aureus isoladas de pacientes com fibrose cística}

Staphylococcus aureus resistentes à oxacilina (MRSA) são, atualmente, um problema global. Pacientes com fibrose cística (FC) são frequentemente colonizados e infectados por MRSA. A realização de testes de susceptibilidade acurados é extremamente importante para o manejo da terapia antimicrobiana nesses indivíduos. Nesse estudo, realizamos comparação entre as acurácias de diversos testes de susceptibilidade à oxacilina, em cepas de $S$. aureus isoladas de pacientes com fibrose cística, tanto sensíveis como resistentes à oxacilina, com diferentes tipos de $\mathrm{SCC} m e c$, e utilizando a detecção do gene mecA como método padrão. A sensibilidade e a especificidade do disco de oxacilina, do Etest, e da placa de agar screening com oxacilina foram de $100 \%$. A sensibilidade do disco de cefoxitina foi $85 \%$, com especificidade de $100 \%$. Em cepas clinicamente relevantes, a utilização combinada de mais de um método deveria ser considerada.

\section{REFERENCES}

1. Broekema NM, Van TT, Monson TA, Marshall SA, Warshauer DM. Comparison of cefoxitin and oxacillin disk diffusion methods for detection of mecA-mediated resistance in Staphylococcus aureus in a large-scale study. J Clin Microbiol. 2009; 47:217-9

2. Cauwelier B, Gordts B, Descheemaecker P, Van Landuyt H. Evaluation of a disk diffusion method with cefoxitin (30 microg) for detection of methicillin-resistant Staphylococcus aureus. Eur J Clin Microbiol Infect Dis. 2004;23:389-92.
3. Clinical and Laboratory Standards Institute. Performance standards for antimicrobial susceptibility testing, nineteenth informational supplement, document M100-S19. Wayne: CLSI; 2009.

4. Felten A, Grandry B, Lagrange PH, Casin I. Evaluation of three techniques for detection of low-level methicillin-resistant $S$. aureus (MRSA): a disk diffusion method with cefoxitin and moxalactam, the Vitek 2 system, and the MRSA-screen latex agglutination test. J Clin Microbiol. 2002;40:2766-71.

5. Fernandes CJ, Fernandes LA, Collignon P, Australian Group on Antimicrobial Resistance Cefoxitin resistance as a surrogate marker for the detection of methicillin-resistant Staphylococcus aureus. J Antimicrob Chemother. 2005;55:506-10.

6. Kohner P, Uhl J, Kolbert C, Persing D, Cockerill F $3^{\text {rd }}$. Comparison of susceptibility testing methods with mecA gene analysis for determining oxacillin (methicillin) resistance in clinical isolates of Staphylococcus aureus and coagulase-negative Staphylococcus spp. J Clin Microbiol. 1999;37:2952-61.

7. Miall LS, McGinley NT, Brownlee KG, Conway SP. Methicillin resistant Staphylococcus aureus (MRSA) infection in cystic fibrosis. Arch Dis Child. 2001;84:160-2.

8. Mimica MJ, Berezin EN, Carvalho RLB, Schneider E, Caiaffa-Filho HH. Evaluation of accuracy and cost of four different methods for detection of methicillin resistance in Staphylococcus aureus isolates from paediatric patients hospitalized in Brazil. J Pediatr Infect Dis. 2008;3:47-50.

9. Mimica MJ, Berezin EN, Carvalho RB. Healthcare associated PVL negative methicillinresistant Staphylococcus aureus with SCCmec type IV. Pediatr Infect Dis J. 2009;28:934.

10. Naimi TS, LeDell KH, Como-Sabetti K, Borchardt SM, Boxrud DJ, Etienne J. et al. Comparison of community- and health care-associated methicillin-resistant Staphylococcus aureus infection. JAMA. 2003;290:2976-84.

11. Oliveira DC, de Lencastre H. Multiplex PCR strategy for rapid identification of structural types and variants of the mec element in methicillin-resistant Staphylococcus aureus. Antimicrob Agents Chemother. 2002;46:2155-61.

12. Sakoulas G, Gold HS, Venkataraman L, De Girolami PC, Eliopoulos GM, Qian Q. Methicillin-resistant Staphylococcus aureus: comparison of susceptibility testing methods and analysis of mecA-positive susceptible strains. J Clin Microbiol. 2001;39:3946-51.

13. Sharp SE, Warren JA, Thomson RB Jr. Cefoxitin disk diffusion screen for confirmation of oxacillin-resistant Staphylococcus aureus isolates and utility in the clinical laboratory. Diagn Microbiol Infect Dis. 2005;51:69-71.

14. Skov R, Smyth R, Clausen M, Larsen AR, Frimodt-Moller N, Olsson-Liljequist B, et al. Evaluation of a cefoxitin $30 \mu \mathrm{g}$ disc on Iso-sensitest agar for detection of methicillinresistant Staphylococcus aureus. J Antimicrob Chemother. 2003;52:204-7.

15. Swenson JM, Tenover FC, Cefoxitin Disk Study Group. Results of disk diffusion testing with cefoxitin correlate with presence of mecA in Staphylococcus spp. J Clin Microbiol. 2005;43:3818-23.

16. Vannuffel P, Gigi J, Ezzedine H, Vandercam B, Delmee M, Wauters G, et al. Specific detection of methicillin-resistant Staphylococcus species by multiplex PCR. J Clin Microbiol. 1995;33:2864-7.

17. Velasco D, del Mar Tomas M, Cartelle M, Beceiro A, Perez A, Molina F, et al. Evaluation of different methods for detecting methicillin (oxacillin) resistance in Staphylococcus aureus. J Antimicrob Chemother. 2005;55:379-82.

18. Weller TMA, Crook DW, Crow MR, Ibrahim W, Pennington TH, Selkon JB. Methicillin susceptibility testing of staphylococci by Etest and comparison with agar dilution and mecA detection. J Antimicrob Chemoter. 1997;39:251-3. 